\title{
In situ Lithium and Boron isotope determinations in mica, pyroxene, and serpentine by LA-MC-ICP-MS
}

\author{
Martin Céline ${ }^{1, *}$, Ponzevera Emmanuel ${ }^{2,3}$, Harlow George ${ }^{1}$
}

${ }^{1}$ Department of Earth and Planetary Sciences, American Museum of Natural History, NY, NY100245192, USA

${ }^{2}$ Lamont-Doherty Earth Observatory, Columbia University, Palisades, NY10964, USA

${ }^{3}$ Institut Carnot Ifremer - EDROME, Département Ressources physiques et Écosystèmes de fond de Mer (REM), Laboratoire Géochimie Métallogénie, Z.I. Pointe du diable, 29280 Plouzané, France

* Corresponding author : Céline Martin, email address : cmartin@amnh.org

\begin{abstract}
:
Boron and $\mathrm{Li}$ are light, incompatible elements that preferentially partition into the liquid phase, whether melt or aqueous fluid, and thus are useful for tracking fluid-related processes in rocks. Most of the $\mathrm{Li}$ isotopic data presently available on subduction-related rocks are from whole-rock analyses; and the B isotopic analyses of subduction material have been carried out either on whole-rocks or in-situ on an accessory phase, such as tourmaline. The new method presented here couples an ESI New Wave UP. 193-FX $\operatorname{ArF}^{*}(193 \mathrm{~nm})$ excimer laser-ablation microscope with a Neptune Plus (Thermo Scientific) MCICP-MS aiming to measure both $\mathrm{Li}$ and $\mathrm{B}$ isotopes in situ with good spatial resolution (metamorphic minerals are commonly chemically zoned, and whole-rock analyses lose this detail). The data thus obtained are compared with SIMS analyses on the same mineral samples for B, and with MC-ICP-MS analyses on whole-rock or mineral separates from the same sample for Li. Additionally, data acquired on tourmaline standards were compared to SIMS values. The results show that for B concentrations above $5 \mu \mathrm{g} / \mathrm{g}$, the data obtained by LA-MC-ICP-MS and by SIMS are identical within error, for mica (phengitic muscovite), pyroxene (jadeite), serpentine (antigorite), and tourmaline. For Li concentrations above $10 \mu \mathrm{g} / \mathrm{g}$, the data obtained by LA-MC-ICP-MS and by MC-ICP-MS are also identical, within error, for mica (phengitic muscovite), and pyroxene (jadeite). However, analyses of tourmaline standards have shown significant differences with reference values, so LA-MC-ICP-MS does not yet appear to be an appropriate method to analyze Li isotopes in tourmalines. Thus, LA-MC-ICP-MS is a suitable method to measure $\mathrm{Li}$ and $\mathrm{B}$ isotopes with good spatial resolution in major rock-forming silicates from subductionrelated rocks where concentrations exceed $10 \mu \mathrm{g} / \mathrm{g}$ and $5 \mu \mathrm{g} / \mathrm{g}$, respectively, with an error on individual measurements equal to or less than previously used methods, but obtainable in a significantly shorter amount of time. The external reproducibility is \pm 2.88 to $3.31 \%$ for $\mathrm{B}$ and \pm 1.50 to 1.75 for $\mathrm{Li}$, which is lower than or equal to the variations encountered within a given chemically zoned sample (up to $10 \%$ of variation within a given natural sample).
\end{abstract}




\section{Highlights}

- $\mathrm{B}$ and Li isotopes in situ by LA-MC-ICP-MS $>$ Analyses in silicates (pyroxene, mica, serpentine) and tourmaline standard material - LA-MC-ICP-MS data compared to traditional methods (SIMS and MCICP-MS) - Suitable method for B isotopes for all minerals considered, short time span. Suitable method for $\mathrm{Li}$ isotopes for pyroxene and mica.

Keywords : Boron isotopes, Lithium isotopes, LA-MC-ICP-MS, subduction zone related silicates 


\section{Introduction}

Lithium and B are incompatible light elements that preferentially partition into the liquid phase during fluid-rock and melt-rock interactions, and thus have proved useful for tracking fluidrelated processes in rocks. Both $\mathrm{Li}$ and $\mathrm{B}$ have two isotopes $\left({ }^{6} \mathrm{Li}\right.$ and ${ }^{7} \mathrm{Li} ;{ }^{10} \mathrm{~B}$ and $\left.{ }^{11} \mathrm{~B}\right)$ that can be strongly fractionated among coexisting phases in nature, depending on the nature of the phases (mineralogy, fluid), the coordination of $\mathrm{B}$ or $\mathrm{Li}$, and temperature. Lithium isotopes in whole-rocks were measured by mass spectrometry for the first time in the late 1950's (Smales and Webster, 1958) whereas the first measurements of B isotopes in whole-rocks by mass spectrometry were performed in the 1940's (e.g. Inghram, 1946, Thode et al., 1948). In subduction-related rocks, Li isotopes are still mainly measured in whole-rock metabasites and metasediments (e.g., Penniston-Dorland et al., 2012; Penniston-Dorland et al., 2010), and in rare cases in mineral separates (e.g., Simons et al., 2010, Penniston-Dorland et al., 2010). These measurements were performed by solution MC-ICP-MS after acid digestion and chromatographic purification through ion exchange resins. Only a few published values have resulted from an in situ method (Secondary lonization Mass Spectrometry - SIMS) and to our knowledge, none on subduction-related rocks. Boron isotope measurements are mainly performed on whole-rock samples, but such measurements are difficult to perform because $B$ is highly volatile, lost during wet chemical processing (e.g., Xiao et al., 1997) and subject to laboratory contamination (borosilicate glassware). However, few studies of B isotopes have been performed on whole-rocks related to deep subduction (e.g., Peacock and Hervig, 1999) or on serpentinites (e.g., Benton et al., 2001) The majority of the available B isotopic data on subduction zone samples have been measured by SIMS on the accessory mineral tourmaline (Nakano and Nakamura, 2001; Bebout et al., 2013; Marschall et al., 2006). In this work, we present a set of Li and B isotope data obtained in situ by LA-MC-ICP-MS on reference materials and samples from the Guatemala Suture Zone (GSZ; eclogites, jadeitites, mica-rocks, serpentinites: Harlow et al. 2011, Flores et al. 2013). Actually, most of the minerals exhumed 
from subduction zones record significant chemical zoning (e.g., Essene and Fyfe, 1967; Harlow, 1994; Harlow et al., 2015), therefore it is important to measure both Li and B isotopes in correlation with the zoning to accurately assess the geochemical processes responsible for the variations, particularly the successive pulses of fluids. A similar in situ method was developed for B isotopes in carbonates (Fietzke et al., 2010) and tourmalines (Míková et al., 2014) but based on the importance of $B$ as a fluid tracer in subduction processes, we believed it was necessary to validate this method for major silicates (mica, pyroxene, and serpentine) in subduction-related rocks. To our knowledge, only one paper was published on Li isotopes acquired by LA-MC-ICP-MS, on synthetic and natural glasses (LeRoux, 2010). As for B, we estimated it was necessary to validate this in situ method on a larger range of minerals encountered in subduction zones.

\section{Experimental}

Laser ablation coupled with multi-collector mass spectrometer (LA-MC-ICP-MS)

Lithium and boron isotopic ratios have been measured in situ using LA-MC-ICP-MS at LamontDoherty Earth Observatory (LDEO - Columbia University). The system couples an ESI New Wave UP-193-FX $\operatorname{ArF}^{*}$ (193 nm) excimer laser ablation microscope with a Neptune Plus (Thermo Scientific) MC-ICP-MS. The Neptune Plus is a high resolution double focusing multicollector ICPMS equipped with ten Faraday cups and five ion counters.

The Neptune Plus yields B peaks with flat tops while working at medium resolution (MR) to avoid the interferences of ${ }^{40} \mathrm{Ar}^{4+}$ and ${ }^{20} \mathrm{Ne}^{2+}$ with ${ }^{10} \mathrm{~B}^{+}$(Fig. 1). Measurements of $\mathrm{B}$ were made using either two Faraday cups or two ion counters over a mass range of 10-11 amu, which 
allows simultaneous measurement of ${ }^{10} \mathrm{~B}$ and ${ }^{11} \mathrm{~B}$. Ion counters are used to increase the available signal for low-B samples and/or permit reduced spot sizes. The Neptune Plus also produces Li-peaks with flat tops when working at both low (LR) and medium (MR) mass resolution (Fig. $1 \mathrm{~b}$ and $1 \mathrm{c}$ ). $\mathrm{Li}$ isotopes are measured using two Faraday cups over a mass range of 6-7 amu, which allows simultaneous measurement of ${ }^{6} \mathrm{Li}$ and ${ }^{7} \mathrm{Li}$.

The intensities measured for ${ }^{6} \mathrm{Li},{ }^{7} \mathrm{Li},{ }^{10} \mathrm{~B}$, and ${ }^{11} \mathrm{~B}$, used to calculate ${ }^{7} \mathrm{Li} /{ }^{6} \mathrm{Li}$ and ${ }^{11} \mathrm{~B} /{ }^{10} \mathrm{~B}$, are corrected from instrument background. The instrumental background is $<0.1 \mathrm{mV}$ on ${ }^{10} \mathrm{~B}$ and $<1$ $\mathrm{mV}$ on ${ }^{11} \mathrm{~B}$ when measurements are made with Faraday cups $(\mathrm{Fc})$, and $<1000 \mathrm{cps}$ on ${ }^{10} \mathrm{~B}$ and $<$ $5000 \mathrm{cps}$ on ${ }^{11} \mathrm{~B}$ when measurements are made with lon Counters (IC). The instrumental background is $<1 \mathrm{mV}$ on ${ }^{6} \mathrm{Li}$ and $<5 \mathrm{mV}$ on ${ }^{7} \mathrm{Li}$ when measurements are performed in $\mathrm{LR}$, and $<$ $1 \mathrm{mV}$ on ${ }^{6} \mathrm{Li}$ and $<2 \mathrm{mV}$ on ${ }^{7} \mathrm{Li}$ when measurements are performed in MR. .

Results are expressed as a permil (\%o) deviation from the isotopic composition of the reference material (i).

(i)

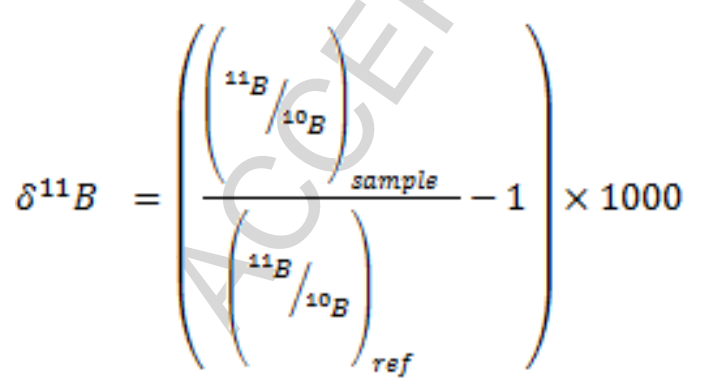

where ${ }^{11} B /{ }^{10} B_{\text {sample }}$ is the isotopic ratio of the sample and ${ }^{11} B /{ }^{10} B_{\text {ref }}$ is the isotopic ratio of the reference material SRM 951 (U.S. National Institute of Standards and Technology, NIST). The same expression of $\delta$ can be written for $\mathrm{Li}$ (with ${ }^{7} \mathrm{Li} / \mathrm{Li}_{\text {sample }}$ and ${ }^{7} \mathrm{Li} / \mathrm{Li}_{\text {ref }}$ ), where L-SVEC (NIST SRM 8545) is used as reference material. As SRM 951 was not available for our measurements, NIST 610 (U.S. National Institute of Standards and Technology, NIST) was used as a secondary standard for measurements by Faraday cups, and NIST 612 (U.S. 
National Institute of Standards and Technology, NIST) for measurements by ion counters. As LSVEC was not available for our measurements, NIST 612 was used to bracket Li isotopic measurements in LR and NIST 610 in MR. Thus, the isotopic ratios $\left({ }^{11} \mathrm{~B} /{ }^{10} \mathrm{~B}\right.$ and $\left.{ }^{7} \mathrm{Li} /{ }^{6} \mathrm{Li}\right)$ of the sample had to be corrected from the use of secondary standards, following equation (ii). The same equation can be written for $\mathrm{Li}$ (with ${ }^{7} \mathrm{Li}^{6} \mathrm{Li}_{\text {sample, }}{ }^{7} L i^{6} L i_{\text {meas }},{ }^{7} L i{ }^{6} L i_{\text {standard, }}$ and ${ }^{7} L i{ }^{6} L i_{\text {std_meas }}$ ).

$$
\left({ }^{11_{B}} /{ }^{10} B\right)_{\text {sample }}=\left({ }^{11_{B}} /{ }^{10} B\right)_{\text {meas }} \times \alpha
$$

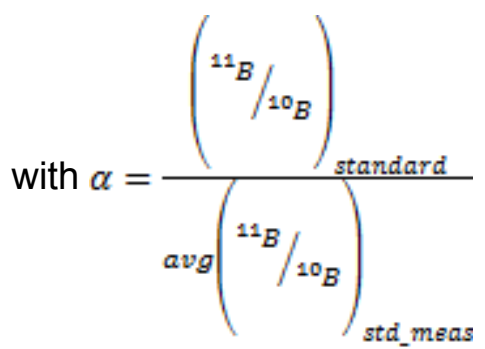

where ${ }^{11} \mathrm{~B} /{ }^{10} \mathrm{~B}_{\text {meas }}$ is the isotopic ratio of the sample measured by LA-MC-ICP-MS, and $\alpha$ the ratio of the reported isotopic ratio for a given secondary standard divided by the average of the measured isotopic ratios before and after the sample (standard bracketing) for a given secondary standard.

The certified value for SRM 951 is ${ }^{11} B /{ }^{10} B_{\text {ref }}=4.044$ (Catanzaro et al., 1970), and the reported ratios of 4.041 (Fietzke et al., 2010) and 4.048 (Jochum and Stoll, 2008) were taken for NIST 610 and NIST 612 respectively. The certified value for L-SVEC (NIST SRM 8545) is ${ }^{7} \mathrm{Li}^{6} \mathrm{Li}_{\text {ref }}=$ 12.173 (Flesch et al., 1973), and the reported ratios of 12.568 and 12.553 (Kasemann et al., 2005) were taken for NIST 610 and NIST 612, respectively.

At a given energy, changing the laser spot size induces a change in the fluence (monitored energy density) at the sample surface, which in turn, generates an isotopic fractionation. By lasering the same standard and only varying the spot size, we observed an isotopic deviation 
that is strongly correlated to the intensity of the signal. A plot of signal intensity versus measured $\delta^{11} \mathrm{~B}$ or $\delta^{7} \mathrm{Li}$ yields a straight line: $R^{2}=0.92$ to 0.99 , (Fig $2 a, 2 b$, the different correlations correspond to different analytical sessions for $B$ ) from which equations ( $i i_{B}$ and $\mathrm{ii}_{\llcorner\mathrm{i}}$ ) will be used to yield a corrected result:

$$
\begin{aligned}
& \text { (iii } \left.i_{\mathrm{B}}\right) \quad \delta^{11} B_{\text {corrected }}=\delta^{11} B-\left(a \times I_{11_{B}}+b\right) \text {, and } \\
& \text { (iii } \left.i_{L i}\right) \quad \delta^{7} L i_{\text {corrected }}=\delta^{7} L i-\left(c \times I_{7_{L i}}+d\right)
\end{aligned}
$$

where $a$ is the slope and $b$ is the intercept of the straight line plot for B analyses, $c$ is the slope and $d$ is the intercept of the straight line plot for Li analyses, and $I_{11_{B}}$ and $I_{7_{L i}}$ are the average intensities of ${ }^{11} \mathrm{~B}$ and ${ }^{7} \mathrm{Li}$ during the measurement. All individual measurements presented in the following are given with a propagated uncertainty taking into account the internal precision of a single ${ }^{11} \mathrm{~B} /{ }^{10} \mathrm{~B}_{\text {meas }}$ (resp. ${ }^{7} \mathrm{Li} /{ }^{6} \mathrm{Li}_{\text {meas }}$ ), and the uncertainties on the different parameters of the equations (iii), determined with Isoplot software (Ludwig et al., 1999). The averages are given with uncertainties of 2 Standard Deviation (2 S.D.).

The laser spot size and mass resolution need to be adjusted to produce signals of comparable intensities $([\mathrm{B}]=6$ to $17,000 \mu \mathrm{g} / \mathrm{g}$, $[\mathrm{Li}]=15$ to $18,000 \mu \mathrm{g} / \mathrm{g})$ for standards and samples. For measuring $B$ isotopes, the laser spot diameter was varied from $25 \mu \mathrm{m}$ for the tourmaline standard to $175 \mu \mathrm{m}$ for samples when measurements were performed with Faraday cups; and from 10 to $175 \mu \mathrm{m}$, when measurements were performed with ion counters. However, most of the measurements on samples using Faraday cups were done with a $175 \mu \mathrm{m}$ spot size, and using ion counters a 25 to $175 \mu \mathrm{m}$ spot size. For Li isotopes, the laser spot diameter was varied from $5 \mu \mathrm{m}$ to $175 \mu \mathrm{m}$, but $150 \mu \mathrm{m}$, in both LR and MR modes, was used predominantly. Measurements were performed continuously along traverses measuring between 270 and 350 $\mu \mathrm{m}$ in length. 
It must be noted that for low intensities, (i.e., below $50,000 \mathrm{cps}$ on ${ }^{11} \mathrm{~B}$ ) the deviation might not follow the regression line (Fig. 2a). Consequently, the samples with B concentrations below $\sim 3$ - $5 \mu \mathrm{g} / \mathrm{g}$ must still be analyzed by SIMS, which has a lower detection limit (below $0.5 \mu \mathrm{g} / \mathrm{g}$, Marschall and Monteleone, 2014).

All of these measurements were performed with a repetition rate of $10 \mathrm{~Hz}$ and a fluence of $\sim 10$ $\mathrm{J} / \mathrm{cm}^{2}$ on the sample surface. To clean the surface prior to measurement (to remove residues of carbon or gold coating, projection of material from a previous ablation track in close vicinity, or other contamination), a pre-ablation traverse was performed with a larger spot size (160 to $200 \%$ of the spot size used for analysis) and a lower frequency $(5 \mathrm{~Hz})$. Each analysis lasted between 1.5 and 2 minutes.

\section{Additional techniques}

Boron isotopes were also determined in situ by SIMS using a Cameca IMS1280 ion microprobe at the North-Eastern National Ion Microprobe Facility (NENIMF) at the Woods Hole Oceanographic Institution. The method described in detail by Marschall and Monteleone (2014) was used to perform analyses on pyroxene $([B]=4 \mu \mathrm{g} / \mathrm{g}$ ). A reduction of the spot size (30-35 $\mu \mathrm{m}$ in diameter) was applied for analyses in mica and serpentine ([B] = $10-100 \mu \mathrm{g} / \mathrm{g}$ ); all the other parameters remain identical.

In situ analyses of $\mathrm{Li}$ and $\mathrm{B}$ concentrations were performed on natural reference materials and samples using the same ESI New Wave UP-193-FX $\operatorname{ArF}^{*}(193 \mathrm{~nm})$ excimer laser coupled to a VG PQ ExCell (Thermo Scientific) ICP-MS (Lamont Doherty Earth Observatory, Columbia University). The following isotopes were monitored: ${ }^{6} \mathrm{Li},{ }^{7} \mathrm{Li},{ }^{11} \mathrm{~B},{ }^{27} \mathrm{Al},{ }^{29} \mathrm{Si}$, and ${ }^{31} \mathrm{P}$. Analyses were performed using traverses $(\sim 300 \mu \mathrm{m}$ long, with a diameter varying between 40 and 150 
$\mu \mathrm{m}$, depending upon the material analyzed) at a repetition rate of $10 \mathrm{~Hz}$ and a monitored energy density of $10 \mathrm{~J} / \mathrm{cm}^{2}$ on the sample surface. Using ${ }^{29} \mathrm{Si}$ as an internal standard (or ${ }^{31} \mathrm{P}$ for a phosphate standard), quantification was performed via external calibration using several glass reference materials (USGS natural glasses BHVO, BIR and BCR). Based on the standards and settings described, external reproducibility for the elements measured was typically ca. $20 \%$ relative standard deviation.

\section{Reference materials and samples}

Samples (unknowns) were cast in $25.4 \mathrm{~mm}$ (1-inch) diameter epoxy resin mounts and reference materials in $12.7 \mathrm{~mm}(1 / 2$-inch) mounts. All were ground and polished using SiC disks, then finished with $\mathrm{Al}_{2} \mathrm{O}_{3}$ slurries $(1 \mu \mathrm{m}$ and $0.3 \mu \mathrm{m})$, and re-polished between each analytical session to erase laser or SIMS pits. Prior to analysis they were cleaned with acetone and then Millipore water $(18.2 \mathrm{M} \Omega . \mathrm{cm})$ in an ultrasonic bath. This combination of mounts allowed us to load the reference materials and sample together in the laser cell, decreasing the risk of possible instability of the signal due to frequent opening of the chamber. Both samples and reference materials were coated with gold for SIMS analyses.

NIST SRM 610 standard was used to bracket and monitor B isotopes when measurements were performed with Faraday cups, whereas NIST SRM 612 was used with ion counters. The $\delta^{11} \mathrm{~B}$ values reported against NIST SRM 951 in the literature for NIST SRM 610 range from $-1.31 \pm 0.68 \%$ (Kasemann et al., 2001) to $0.0 \pm 0.3 \%$ (Jochum et al., 2011), depending upon the method used for measurement (Table 1). For NIST SRM 612, the $\delta^{11} \mathrm{~B}$ values accepted in the literature range from $-1.07 \pm 0.85 \%$ (Kasemann et al., 2001) to $+0.1 \pm$ $0.5 \%$ (Jochum et al., 2011) (Table 1). NIST SRM 610 and NIST SRM 612 are expected to be 
isotopically homogeneous for B isotopes (Kasemann et al., 2001). Additionally, the tourmaline standards H-98144 (elbaite), H-108976 (dravite), and H-112566 (schorl) (Dyar et al., 2001) were analyzed as unknown samples during B isotopic analyses and then, after correction (as cited above), were compared to literature values. To our knowledge, the isotopic homogeneity of the tourmalines has never been evaluated. The International Atomic Energy Agency (IAEA) standard glasses B6 (Tonarini et al., 2003) and GOR132-G (Jochum et al., 2006), mounted in iridium, were used to monitor B analysis during SIMS analysis.

NIST SRM 610 standard was used to bracket and monitor Li isotopes when measurements were performed in MR mode, and NIST SRM 612 was used to bracket and monitor $\mathrm{Li}$ isotopes in LR mode. The $\delta^{7} \mathrm{Li}$ reported values from the literature for NIST SRM 610 against L-SVEC range from $+22.7 \pm 0.3 \%$ to $+32.5 \pm 1.3 \%$ (Kasemann et al., 2005, Table 1) The GeoReM preferred value, defined for standards with only few certified data available, is +32.5\% (Jochum and Stoll, 2008). These values were mostly obtained by SIMS and one by MC-ICP-MS; none were obtained by LA-MC-ICPMS. The accepted $\delta^{7}$ Li values for NIST SRM 612 range from $+22.8 \pm 0.3$ to $+35.3 \pm 0.8 \%$ (Kasemann et al., 2005; Magna et al., 2004, Table 1) and the GeoReM preferred value is $+31.2 \%$ (Jochum and Stoll, 2008). These values were obtained either by SIMS, TIMS, or MC-ICP-MS. Kasemann et al., (2005) highlighted that the values of $\delta^{7} \mathrm{Li}$ of NIST SRM 610 and NIST SRM 612 obtained by SIMS are systematically lower (by $10 \%$ ) than the ones obtained by MC-ICP-MS and TIMS. They explained that difference as a matrix effect due to high $\mathrm{Si}$ content (up to $70 \mathrm{wt} \% \mathrm{SiO}_{2}$, whereas most of the natural basaltic glasses used as reference material (e.g., BHVO-1, BIR-1) contain around 50 wt. \% $\mathrm{SiO}_{2}$ ). However, NIST SRM 610 and NIST SRM 612 are considered isotopically homogeneous for Li when analyzed by SIMS. When NIST SRM 610 was used to bracket and monitor the isotopic measurement, i.e., in MR mode, NIST SRM 612 is measured as an unknown. When NIST SRM 612 was used to bracket and monitor the isotopic measurement, i.e., in LR mode, 
NIST SRM 610 is measured as an unknown. Thus, the values obtained for these measurements are compared, after correction, to the reference value for each standard. Additionally, the tourmaline standards $\mathrm{H}-98144$ and $\mathrm{H}-112566$ (schorl) were analyzed as unknowns during $\mathrm{Li}$ analyses. Only H-98144 was already analyzed for Li isotopes by SIMS (Ludwig et al., 2005), and its isotopic homogeneity was not tested further. Finally, the spodumene $\mathrm{H}-80017\left(\mathrm{LiAlSi}_{2} \mathrm{O}_{6}\right)$ and the lithiophilite $\mathrm{H}-134825\left(\mathrm{LiMn}^{2+} \mathrm{PO}_{4}\right)$, for which $\mathrm{Li}$ isotopic data are not available to our knowledge, were analyzed during this work.

\section{Results and discussion}

Results on reference materials used for monitoring

As NIST SRM 951 and L-SVEC standards were not run during any of these measurements, the results presented here for NIST SRM 610 and NIST SRM 612 give an estimation of the accuracy and reproducibility of our method. The individual measurements acquired on NIST SRM 610 and NIST SRM 612 for both B and Li isotopes are available as Supplementary Material. The B isotopes measured on NIST SRM 610, when used to monitor the measurements (i.e., when B isotopes are measured on Faraday cups), give an average of $\delta^{11} \mathrm{~B}$ $=-0.27 \pm 2.88 \%$ o $(n=94$, Table 1, Fig. 3a) after corrections detailed above. In case of measurements performed with ion counters, NIST SRM 612 is used to monitor the measurements, and the average obtained for $\delta^{11} \mathrm{~B}$ after correction is $+0.68 \pm 3.31 \%$ o $(n=262$, Table 1, Fig. 3b). When NIST SRM 610 standard was used to monitor Li isotope measurements, it yielded a corrected average of $+32.4 \pm 1.5 \%$ ( $n=50$, Table 1, Fig. 3c) in MR mode. When NIST SRM 612 is used to monitor Li isotope measurements in LR mode, a 
corrected average of $+31.3 \pm 1.7 \%(n=102$, Table 1 , Fig $3 d)$ was obtained. The long-term reproducibility has to be considered on a large amount of data, and analyzed during each analytical session. Thus, the values of 2 S.D. obtained on NIST 610 and NIST 612 used for monitoring are taken as our external, long-term reproducibility.

\section{Results on reference materials}

The $\delta^{11} \mathrm{~B}$ values from tourmaline reference materials were measured only using Faraday cups, because the $B$ concentration is too high to be measured by ion counters. The previously published values range from -10 to $-12 \%$ for $\mathrm{H}-98144$, from -6.5 to $-7.6 \%$ for $\mathrm{H}-108796$, and from -10.6 to $-12.8 \%$ for $\mathrm{H}-112566$. They were obtained either by fusion and TIMS analyses or in situ by SIMS (Leeman and Tonarini, 2001; Trumbull et al., 2009). No published measurements obtained by LA-MC-ICPMS exist. Our measurements, after correction, give an average of $-10.2 \pm 4.1 \%$ for $\mathrm{H}-98144(n=15$, Fig. 4, Table 1$),-3.5 \pm 2.6 \%$ for $\mathrm{H}-108796(n=$ 3), and $-12.5 \pm 1.6 \%$ for $H-112566(n=1)$ (Table 1$)$. The values reported here overlap the recommended values of $-10.4 \pm 0.2 \%$ for $\mathrm{H}-98144,-6.6 \pm 0.7 \%$ for $\mathrm{H}-108796$, and $-12.5 \pm 1.6$ $\%$ for $\mathrm{H}-112556$ (Leeman and Tonarini, 2001). The reproducibility of $\mathrm{H}-98144$ is not as good as the long-term reproducibility for B (2.88 to $3.25 \%$ ) defined on synthetic reference material, likely because of a smaller population of analyses. As the regression line obtained on synthetic reference material (NIST SRM 610) can retrieve the literature value of tourmalines (natural standards), it is likely that matrix effects are negligible relative to the method precision in our setup (usually \pm 2.88 to $3.25 \%$ ). Míková et al., (2014) observed a bias of up to $2.5 \%$ for $\delta^{11} \mathrm{~B}$ in tourmaline if a non-matrix matched reference material is used to calibrate the measurements, which is lower than our method precision. 
Analysis of NIST SRM 612 standard as an unknown yielded a corrected average value of $\delta^{7} \mathrm{Li}=$ $+28.9 \pm 4.7 \%$ o $(n=8$, Table 1 , Fig. $5 a)$, in the range of the previously published values. For NIST SRM 610 standard, the average corrected value is $\delta^{7} \mathrm{Li}=+35.2 \pm 8.0 \%(\mathrm{n}=24$, Table 1 , Fig. 5b), in the range within error of the previously published values. However, the values are scattered between the different sessions of analyses but homogeneous within each session (see Supplementary Material). In addition, this standard was run twice with a larger spot size of $50 \mu \mathrm{m}$ on NIST SRM 610 ([Li] $\sim 470 \mu \mathrm{g} / \mathrm{g}$ ), which led to a signal greater than $2 \mathrm{~V}$ on ${ }^{7} \mathrm{Li}$, and the corrected $\delta^{7} \mathrm{Li}$ values were significantly higher and beyond the range of published values $(+57.3$ \pm 10.0 and $+52.5 \pm 9.8 \%$, Fig. 5 b; Supplementary Material). Thus, a bias similar to that observed for a very low signal in B may exist for a strong signal, leading to an overestimate of $\delta^{7} \mathrm{Li}$. To avoid a similar bias in measurements of unknowns, the spot size should be optimized to intensities below or equal to $1.5 \mathrm{~V}$ on ${ }^{7} \mathrm{Li}$, which should yield accurate values from the standards. Two Li-rich standards had not been analyzed previously for $\mathrm{Li}$ isotopes: spodumene $\mathrm{H}-80017\left(\mathrm{LiO}_{2}=7.75-7.83\right.$ wt. \%, Dyar et al., (2001)) and lithiophilite $\mathrm{H}-134825\left(\mathrm{LiO}_{2}=8.43\right.$ wt.\%, Dyar et al., (2001)). Our analysis by LA-MC-ICPMS, in both LR and MR modes, yield similar values of $\delta^{7} \mathrm{Li}$ for each standard (Table 1). Spodumene $\mathrm{H}-80017$ might not be isotopically homogeneous, with values ranging from $+19.1 \pm 1.5$ to $+13.4 \pm 1.2 \%$ (Table 1). Tourmaline $\mathrm{H}$ 98144 has been measured by SIMS: $\delta^{7}$ Li ranges from +7.1 to $7.5 \%$ (Ludwig et al., 2011; Marschall, pers. comm.). The corrected $\delta^{7} \mathrm{Li}$ obtained here by LA-MC-ICPMS is $+32.1 \pm 2.3 \%$ $(n=3$, Table 1) in LR mode and $+13.0 \pm 5.8 \%(n=11$, Table 1$)$ in MR mode. Tourmaline standard H-112566 has been measured by SIMS and yielded $\delta^{7} \mathrm{Li}$ of $+5.6 \pm 0.2 \%(n=2$; Marschall, pers. comm.). The LA-MC-ICPMS results are $+23.6 \pm 6.4 \%$ ( $n=3$, Table 1$)$ in LR mode and $+9.9 \pm 2.7 \%(n=10$, Table 1$)$ in MR mode. For this case, the difference between values obtained in LR and MR modes is large (15 to $20 \%$ ). The $\delta^{7} \mathrm{Li}$ of tourmaline obtained in MR mode by LA-MC-ICPMS are definitely closer to those obtained by SIMS, although they are 
higher by 4 to $5 \%$. Three hypotheses are considered to explain the mismatching measurements of $\delta^{7} \mathrm{Li}$ in tourmaline by LA-MC-ICPMS. First, there may be a ${ }^{14} \mathrm{~N}^{++}$spectral interference at mass 7. A recent paper demonstrated that tourmaline could incorporate significant amount of $\mathrm{NH}_{4}$ (up to $500 \mu \mathrm{g} / \mathrm{g}$ in natural samples) in its crystal lattice (Wunder et al., 2015). However, such interference would create a ca. $9 \mathrm{mV}$ signal intensity that would be visible on a mass scan. Additionally, mica also incorporates significant amount of $\mathrm{NH}_{4}$, in the same order of magnitude as that recorded in tourmaline (e.g., Boyd, 1997; Wunder et al., 2015), and its $\delta^{7} \mathrm{Li}$ is similar whether it is analyzed by MC-ICP-MS or LA-MC-ICPMS. Second, tourmaline is pyroelectric (e.g., Hawkins et al., 1995), and it may have an impact on Li ion behavior in the sample or the laser cell. Third, the assignment of the trace-element cations to the crystallographic sites is still ambiguous in tourmaline (Henry et al., 2011). $\mathrm{Li}^{+}$is found in the 6fold coordinated $Y$ site, along with $\mathrm{Al}^{3+}$, (with a general formula $\left.X Y_{3} Z_{6}\left(T_{6} O_{18}\right)\left(B O_{3}\right) V_{3} W\right)($ Henry et al., 2011), but it might also be present in the $\mathrm{X}$ site, in substitution of $\mathrm{Na}^{+}$or $\mathrm{K}^{+}$, as demonstrated for mica by Brigatti and Guggenheim (2002). Thus, if the $\mathrm{NH}_{4}$ interference hypothesis is unlikely, there is the possibility that Li may reside in two different crystallographic sites and, consequently, with both different bonding and isotopic fractionation. We are exploring these possibilities.

Results on samples from the Guatemala Suture Zone

As these samples had not been analyzed for B isotopes by any method previously, measurements were performed by LA-MC-ICP-MS, using both Faraday cups and ion counters, and by SIMS, for comparison. Five samples from the Guatemala Suture Zone were selected. $\delta^{11} \mathrm{~B}$ was measured on mica (phengitic muscovite) from one albite-mica rock (MVJ84-29-1: Harlow 1994), two jadeitites (JJE01-X-3 and MVE02-8-5: Harlow et al., 2011) and an eclogite 
(MVE02-6-3: Brueckner et al., 2009). Additionally, some measurements were performed by LAMC-ICP-MS (only ion counters) and by SIMS on jadeitic pyroxene from jadeitite JJE01-X-3 (Harlow et al., 2011), and on antigorite from serpentinite MVE03-18-4. The results presented in Table 2 display the minimum and maximum $\delta^{11} \mathrm{~B}$ for each method and Fig. $6 a, b, c, d, e, f$ displays the individual measurements (i.e., each value represents a single measurement) performed on a given sample. These measurements of natural samples display some variation, but the range of values for a given sample obtained through the different methods overlap one another. Thus, for all types of analyzed samples, the individual $\delta^{11} \mathrm{~B}$ obtained by LA-MC-ICPMS, with either Faraday cups or ion counters, and by SIMS are comparable within propagated uncertainties. The B concentrations measured by LA-ICP-MS are only rarely in agreement with the semi-quantitative estimations made from the intensity of ${ }^{11} \mathrm{~B}$ of the sample compared to the intensity of ${ }^{11} \mathrm{~B}$ of the reference material during isotopic measurements by LA-MC-ICP-MS or SIMS (Table 2). This is likely due to the fact that the intensity of the signal can fluctuate during isotopic measurements, particularly during measurement with ion counters, and the intensity is not normalized. So, no estimation of the B concentrations can be made from LA-MC-ICP-MS or SIMS measurements; they must be determined by LA-ICP-MS.

For Li isotopes, we compared the values obtained by LA-MC-ICP-MS with previously published values obtained by wet chemistry and MC-ICP-MS on the same samples from Guatemala (Simons et al., 2010), specifically jadeite from jadeitite MVE02-8-5 and phengitic muscovite in mica-rocks MVJ84-29-1 and MVJ84-56-3. The results presented in Table 3 and Fig. 7a, b, c are individual measurements, i.e., each value represents a single measurement. Although the minerals display scattered $\delta^{7} \mathrm{Li}$, likely due to the chemical zoning inherited from a complex geological history, the averages calculated from individual measurements on the three samples are in good agreement, within uncertainties, with wet chemistry. The values of $\delta^{7} \mathrm{Li}$ in phengitic mica from mica-rock MVJ84-56-3 are similar within 2 S.D., for both LR and MR modes (Table 
3), to the value by wet chemistry (Simons et al., 2010). The $\delta^{7} \mathrm{Li}$ of jadeite in jadeitite MVE02-8-5 is also in good agreement within uncertainties with the data by wet chemistry (Simons et al., 2010), even though we compare whole-rock data to in situ jadeite data (i.e., jadeite is the Li carrier in the rock). The slight difference observed between the wet chemistry average and the in situ average for the MVJ-84-29-1 could be explained by the heterogeneity of values in the mica from that sample. As the regression line obtained on synthetic reference material (NIST SRM 610 and NIST SRM 612) can retrieve the previously published values of GSZ minerals, it is likely that the matrix effect is negligible compared to the method precision of our setup (usually \pm 1.51 to $1.75 \%$ ). No other measurements have been performed by LA-MC-ICP-MS for $\mathrm{Li}$ isotopes. Although several publications have concluded that SIMS does not produce matrix shifts in the Li isotopic values of natural standards (e.g., Decitre et al., 2002; Ottolini et al., 2002), others have concluded that a significant matrix effect can be seen when Li isotopes are analyzed by SIMS in materials where matrix $\mathrm{Si}$ content is high ( 70 wt $\% \mathrm{SiO}_{2}$, e.g., Kasemann et al., 2005) or in pyroxene and amphibole samples (Marks et al., 2008).

Unlike the case with $\mathrm{B}, \mathrm{Li}$ concentrations estimated by LA-MC-ICP-MS are in reasonable agreement with those acquired by LA-ICP-MS, and/or in the literature. The Li concentrations in phengite from mica-albite rock MVJ84-29-1 are in good agreement when measured by LA-ICPMS or LA-MC-ICP-MS (Table 3), but not with the published value (Simons et al., 2010). This might be due to an artifact in MC-ICP-MS measurements, or to the heterogeneity of the sample. For the lithiophilite standard H-134825, the reference value (Dyar et al., 2001) and LA-ICP-MS measurement for Li concentration are similar, but the LA-MC-ICP-MS measurements lead to a significantly overestimated value (Table 1). In this case, it is likely due to the use of the smallest spot available with the laser (diameter of $5 \mu \mathrm{m}$ ), and according to the formula used for concentration calculation (given Table 1), the smallest inaccuracy in the spot size could yield large variations in the estimate of the concentration. However, except in the case of a very small 
spot diameter, the Li concentrations estimated by LA-MC-ICP-MS are in good agreement with previously published values or LA-ICP-MS measurements.

\section{Summary and conclusions}

The results presented here demonstrate that $\mathrm{B}$ and $\mathrm{Li}$ isotopes can be analyzed in-situ in subduction-related major silicates, (i.e., pyroxene, mica, and serpentinite) by LA-MC-ICP-MS with accuracy and reproducibility similar to other methods. The in-situ measurements of $\delta^{11} \mathrm{~B}$ acquired on a single sample both by SIMS and by LA-MC-ICP-MS lead to the same values, within 2 S.D., for natural phengitic muscovite, jadeitic pyroxene, and antigorite serpentine. The in-situ measurements of Li isotopes by LA-MC-ICP-MS on both synthetic glass standards (NIST SRM 610 and NIST SRM 612) and natural minerals (phengitic muscovite and jadeitic pyroxene) overlap, within uncertainties, those obtained by wet chemistry with TIMS or MC-ICP-MS analyses. In both cases, the matrix effects appear negligible relative to the precision of the method (usually \pm 2.88 to $3.75 \%$ for $B$ isotopes, and \pm 1.50 to $1.75 \%$ for Li isotopes). Thus, LA-MC-ICP-MS is reliable for in-situ analysis of $\mathrm{B}$ and $\mathrm{Li}$ isotopes in a range of subductionrelated silicates and in a short amount of time (about 2 min per analysis), with uncertainties similar to or lower than those associated with SIMS analysis.

Measurements have been carried out on tourmaline reference materials. The values obtained for $B$ isotopes on standards $\mathrm{H}-98144, \mathrm{H}-108796$, and $\mathrm{H} 112566$ are identical to published values; therefore, LA-MC-ICP-MS is a suitable technique to analyze tourmalines. In the case of Li isotopes analyses on $\mathrm{H}-98144$ and $\mathrm{H}-112566$, the values obtained by LA-MC-ICP-MS display a dramatic variation compared to SIMS values $(+25 \%$ ) when the analyses are performed in LR mode, and a moderate variation (+5\%) when analyses are performed in MR mode. The reason 
for this difference is unclear. Thus, LA-MC-ICP-MS is not yet a suitable technique to analyze Li isotopes in tourmaline, and a more detailed study of Li distribution in tourmaline coupled with $\mathrm{Li}$ behavior under a laser beam is necessary to properly address the problem.

\section{Acknowledgements}

Journal reviews from Sarah Penniston-Dorland, and an anonymous reviewer, as well as edition by Klaus Mezger significantly helped to improve this manuscript. The authors are grateful to Horst Marschall for his fruitful discussions and reviews of the present paper, and the share of his $\mathrm{Li}$ isotopic values in tourmaline reference materials. The authors thank the helpful assistance of Louise Bolge at LDEO with the LA-ICP-MS and LA-MC-ICP-MS facilities and access to the MC-ICP-MS by Steve Goldstein. The authors thank the helpful assistance of Brian Monteleone at WHOI with the SIMS facility. Funding for this project by a US NSF grant (EAR-1119403) is gratefully acknowledged. $\mathrm{CM}$ is grateful for a Richard Guilder Graduate School Kalbfleisch postdoctoral fellowship for continued support during this project. 


\section{References}

Bebout, G.E., Agard, P., Kobayashi, K., Moriguti, T., Nakamura, E., 2013. Devolatilization history and trace element mobility in deeply subducted sedimentary rocks: Evidence from Western Alps HP/UHP suites. Chemical Geology, 342(0), 1-20.

Benton, L.D., Ryan, J.G., Tera, F., 2001. Boron isotope systematics of slab fluids as inferred from a serpentine seamount, Mariana forearc. Earth and Planetary Science Letters, 187(3), 273-282.

Brigatti, M.F., Guggenheim, S., 2002. Mica crystal chemistry and the influence of pressure, temperature, and solid solution on atomistic models. Reviews in Mineralogy and Geochemistry, 46(1), 1-97.

Brueckner, H.K., Avé Lallemant, H.G., Sisson, V.B., Harlow, G.E., Hemming, S.R., Sorensen, S. S., Tsujimori, T., Martens, U., 2009. Metamorphic reworking of a high-pressure-low temperature serpentinite-matrix mélange belt along the Motagua fault, Guatemala: A revised record of Neocomian and Maastrichtian transpressional tectonics. Earth and Planetary Science Letters 284, 228-235.

Catanzaro, E.J., 1970. Boric acid: isotopic and assay standard reference materials, 17. National Bureau of Standards, Institute for Materials Research.

Decitre, S., Deloule, E., Reisberg, L., James, R., Agrinier, P., Mével, C., 2002. Behavior of Li and its isotopes during serpentinization of oceanic peridotites. Geochemistry, Geophysics, Geosystems, 3(1), 1-20.

Dyar, M.D., Wiedenbeck, M., Robertson, D., Cross, L.R., Delaney, J.S., Ferguson, K., Francis, C.A., Grew, E.S., Guidotti, C.V., Hervig, R.L., 2001. Reference minerals for the microanalysis of light elements. Geostandards Newsletter, 25(2-3), 441-463. 
Essene, E., Fyfe, W., 1967. Omphacite in Californian metamorphic rocks. Contributions to Mineralogy and Petrology, 15(1), 1-23.

Fietzke, J., Heinemann, A., Taubner, I., Bohm, F., Erez, J., Eisenhauer, A., 2010. Boron isotope ratio determination in carbonates via LA-MC-ICP-MS using soda-lime glass standards as reference material. Journal of Analytical Atomic Spectrometry, 25(12), 1953-1957.

Flesch, G., Anderson Jr, A., Svec, H., 1973. A secondary isotopic standard for ${ }^{6} \mathrm{Li} /{ }^{7} \mathrm{Li}$ determinations. International Journal of Mass Spectrometry and Ion Physics, 12(3), 265272.

Flores, K., Martens, U., Harlow, G.E., Brueckner, H.K., and Pearson, N. 2013. Jadeitite formed during subduction: In situ zircon geochronology constraints from two different tectonic events in the Guatemala Suture Zone. Earth and Planetary Science Letters 371-372, 67-81.

Harlow, G.E., 1994. Jadeitites, albitites and related rocks from the Motagua Fault Zone, Guatemala. Journal of Metamorphic Geology 12, 49-68.

Harlow, G.E., Sisson, V.B., and Sorensen, S.S. 2011. Jadeitite from Guatemala: Distinctions among multiple occurrences. Geologica Acta 9(3), 363-387.

Harlow, G.E., Tsujimori, T., Sorensen, S.S., 2015. Jadeitites and Plate Tectonics. Annual Review of Earth and Planetary Sciences, 43(1).

Inghram, M.G., 1946. The Isotopic Constitution of Tungsten, Silicon, and Boron. Physical Review, 70(9-10), 653.

Ishikawa, T., and Nakamura, E., 1992. Boron isotope geochemistry of the oceanic crust from DSDP/ODP Hole 504B. Geochim. Cosmochim. Acta 56, 1633-1639..

Ishikawa, T., \& Nakamura, E., 1994. Origin of the slab component in arc lavas from across-arc variation of $\mathrm{B}$ and $\mathrm{Pb}$ isotopes. Nature $370,205-208$.

Jochum, K.P., Wilson, S.A., Abouchami, W., Amini, M., Chmeleff, J., Eisenhauer, A., Hegner, E., laccheri, L.M., Kieffer, B., Krause, J., 2011. GSD-1G and MPI-DING Reference Glasses 
for In Situ and Bulk Isotopic Determination. Geostandards and Geoanalytical Research, 35(2), 193-226.

Jochum, K.P., Stoll, B., Herwig, K., Willbold, M., Hofmann, A.W., Amini, M., Aarburg, S., Abouchami, W., Hellebrand, E., Mocek, B., 2006. MPI-DING reference glasses for in situ microanalysis: New reference values for element concentrations and isotope ratios. Geochemistry, Geophysics, Geosystems, 7(2).

Jochum, K.P., Stoll, B., 2008. Reference materials for elemental and isotopic analyses by LA(MC)-ICP-MS: successes and outstanding needs, Laser Ablation ICP-MS in the Earth Sciences: Current practices and outstanding issues. Mineral. Assoc. Can., pp. 147-168. Kasemann, S., Meixner, A., Rocholl, A., Vennemann, T., Rosner, M., Schmitt, A.K., Wiedenbeck, M., 2001. Boron and Oxygen Isotope Composition of Certified Reference Materials NIST SRM 610/612 and Reference Materials JB-2 and JR-2. Geostandards Newsletter, 25(2-3), 405-416.

Kasemann, S.A., Jeffcoate, A.B., Elliott, T., 2005. Lithium isotope composition of basalt glass reference material. Analytical chemistry, 77(16), 5251-5257.

Leeman, W.P., Tonarini, S., 2001. Boron isotopic analysis of proposed borosilicate mineral reference samples. Geostandards Newsletter, 25(2-3), 399-403.

Le Roux, P.J., Shirey, S.B., Benton, L., Hauri, E.H., Mock, T.D., 2004. In situ, multiple-multiplier, laser ablation ICP-MS measurement of boron isotopic composition $(\delta 11 \mathrm{~B})$ at the nanogram level. Chemical Geology 293, 123-138.

Le Roux, P.J., 2010. Lithium isotope analysis of natural and synthetic glass by laser ablation MC-ICP-MS. Journal of Analytical Atomic Spectrometry, 25(7), 1033-1038.

Ludwig, T., Marschall, H., von Strandmann, P.P., Shabaga, B., Fayek, M., Hawthorne, F., 2011. A secondary ion mass spectrometry (SIMS) re-evaluation of B and Li isotopic compositions of Cu-bearing elbaite from three global localities. Mineralogical Magazine, 75(4), 2485-2494. 
Magna, T., Wiechert, U.H., Halliday, A.N., 2004. Low-blank isotope ratio measurement of small samples of lithium using multiple-collector ICPMS. International Journal of Mass Spectrometry, 239(1), 67-76.

Marschall, H.R., Ludwig, T., Altherr, R., Kalt, A., Tonarini, S., 2006. Syros metasomatic tourmaline: Evidence for very high-delta B-11 fluids in subduction zones. Journal of Petrology, 47(10), 1915-1942.

Marschall, H.R., Monteleone, B.D., 2014. Boron Isotope Analysis of Silicate Glass with Very Low Boron Concentrations by Secondary Ion Mass Spectrometry. Geostandards and Geoanalytical Research.

Míková, J., Košler, J., Wiedenbeck, M., 2014. Matrix effects during laser ablation MC ICP-MS analysis of boron isotopes in tourmaline. Journal of Analytical Atomic Spectrometry, 29(5), 903-914.

Ottolini, L., Cámara, F., Hawthorne, F.C., Stirling, J., 2002. SIMS matrix effects in the analysis of light elements in silicate minerals: Comparison with SREF and EMPA data. American Mineralogist, 87(10), 1477-1485.

Peacock, S.M., Hervig, R.L., 1999. Boron isotopic composition of subduction-zone metamorphic rocks. Chemical Geology, 160(4), 281-290.

Penniston-Dorland, S.C., Bebout, G.E., Pogge von Strandmann, P.A.E., Elliott, T., Sorensen, S.S., 2012. Lithium and its isotopes as tracers of subduction zone fluids and metasomatic processes: Evidence from the Catalina Schist, California, USA. Geochimica et Cosmochimica Acta, 77(0), 530-545.

Penniston-Dorland, S.C., Sorensen, S.S., Ash, R.D., Khadke, S.V., 2010. Lithium isotopes as a tracer of fluids in a subduction zone mélange: Franciscan Complex, CA. Earth and Planetary Science Letters, 292(1-2), 181-190. 
Simons, K.K., Harlow, G.E., Brueckner, H.K., Goldstein, S.L., Sorensen, S.S., Hemming, N.G., Langmuir, C.H., 2010. Lithium isotopes in Guatemalan and Franciscan HP-LT rocks: Insights into the role of sediment-derived fluids during subduction. Geochimica et Cosmochimica Acta, 74(12), 3621-3641.

Smales, A.A., Webster, R.K., 1958. The determination of lithium in rocks by the method of stable isotope dilution. Analytica Chimica Acta, 18(0), 587-596.

Thode, H., Macnamara, J., Lossing, F., Collins, C., 1948. Natural variations in the isotopic content of boron and its chemical atomic weight. Journal of the American Chemical Society, 70(9), 3008-3011.

Trumbull, R.B., Krienitz, M.S., Gottesmann, B., Wiedenbeck, M., 2008. Chemical and boronisotope variations in tourmalines from an S-type granite and its source rocks: the Erongo granite and tourmalinites in the Damara Belt, Namibia. Contributions to Mineralogy and Petrology, 155(1), 1-18.

Wunder, B., Berryman, E., Plessen, B., Rhede, D., Koch-Müller, M., Heinrich, W., 2015. Synthetic and natural ammonium-bearing tourmaline. American Mineralogist, 100(1), 250256.

Xiao, Y.K., Vocke, R.D., Swihart, G.H., Xiao, Y., 1997. Boron Volatilization and Its Isotope Fractionation during Evaporation of Boron Solution. Analytical Chemistry, 69(24), 52035207. 


\section{Figure captions}

Fig. 1: Diagrams showing a) the flat tops of Boron isotope peaks as well as the separation of mass interference $\left.\left({ }^{40} \mathrm{Ar}^{4+}+{ }^{10} \mathrm{Ne}^{2+}\right), b\right) \mathrm{Li}$ isotope peaks in $\mathrm{LR}$, and $\left.\mathrm{c}\right) \mathrm{Li}$ isotope peaks in MR.

Fig. 2: Graphs showing a) measured $\delta^{11} \mathrm{~B}$ vs. ${ }^{11} \mathrm{~B}$ signal intensity for different spot sizes on NIST SRM 612 standard (two sets of measurements on two different dates, indicated under the equations). The shaded area shows the intensity region in which the relationship between $\delta^{11} \mathrm{~B}$ and intensity is nonlinear (below $50,000 \mathrm{cps}$, i.e. $\sim 5 \mu \mathrm{g} / \mathrm{g}$ of B). b) $\delta^{7} \mathrm{Li}$ measured vs. intensity of signal on ${ }^{7} \mathrm{Li}$ for different spot sizes on NIST SRM 612 (LR).

Fig. 3: Plot of $\delta^{11} B$ and $\delta^{7} \mathrm{Li}$ measurements for NIST SRM 610 and NIST SRM 612 reference material used to monitor measurements on unknowns. The different sessions of analyses are represented by different colors, and the date of the session is written above. In case of two sessions taking place within the same month, they are identified as (1) and (2), chronologycally. a) NIST SRM 610 (MR, Fc = Faraday cup), b) NIST SRM 612 (MR, IC = Ion Counter), c) $\delta 7 \mathrm{Li}$ corrected for NIST SRM 610 (MR, Fc), and d) $87 \mathrm{Li}$ corrected for NIST SRM 612 (LR, Fc). The reference values are Fietzke et al., (2010) for B, and Jochum and Stoll, (2008) for Li.

Fig. 4: Plot of $\delta^{11} \mathrm{~B}$ measurements for tourmaline (elbaite) reference material H-98144 (analyzed as unknown sample). The reference value is taken from Trumbull et al., (2009). 
Fig. 5: $\delta^{7} \mathrm{Li}$ corrected for standards NIST SRM 610 and NIST SRM 612 analyzed as unknown samples. a) $\delta^{7} \mathrm{Li}$ corrected for NIST SRM 612 (MR, Fc), b) $\delta^{7} \mathrm{Li}$ corrected for NIST SRM 610 $(\mathrm{LR}, \mathrm{Fc})$. The different sessions of analyses are represented by different colors, and the date of the session is written above. The reference values are Jochum and Stoll, (2008).

Fig. 6: Comparison plots of in situ $\delta^{11} \mathrm{~B}$ measurements by LA-MC-ICMPS (Fc and IC) and by SIMS on samples coming from the GSZ. a) phengitic muscovite in mica-albite rock MVJ8429-1, b) phengitic muscovite in jadeitite JJE01-X-3, c) phengitic muscovite in jadeitite MVE02-8-5, d) phengitic muscovite in eclogite MVE02-6-3, e) jadeitic pyroxene in jadeitite JJE01-X-3, and f) antigorite in serpentinite MVE04-18-3.

Fig. 7: Comparison plots of in situ $\delta^{7} \mathrm{Li}$ measurements by LA-MC-ICMPS with data acquired by chemical digestion and MC-ICP-MS measurements on the same samples from the GSZ (Simons et al., 2010). a) jadeitic pyroxene in jadeitite MVE02-8-5, b) phengitic muscovite in mica-albite rock MVJ84-29-1, and c) mica in mica-albite rock MVJ84-56-3. 

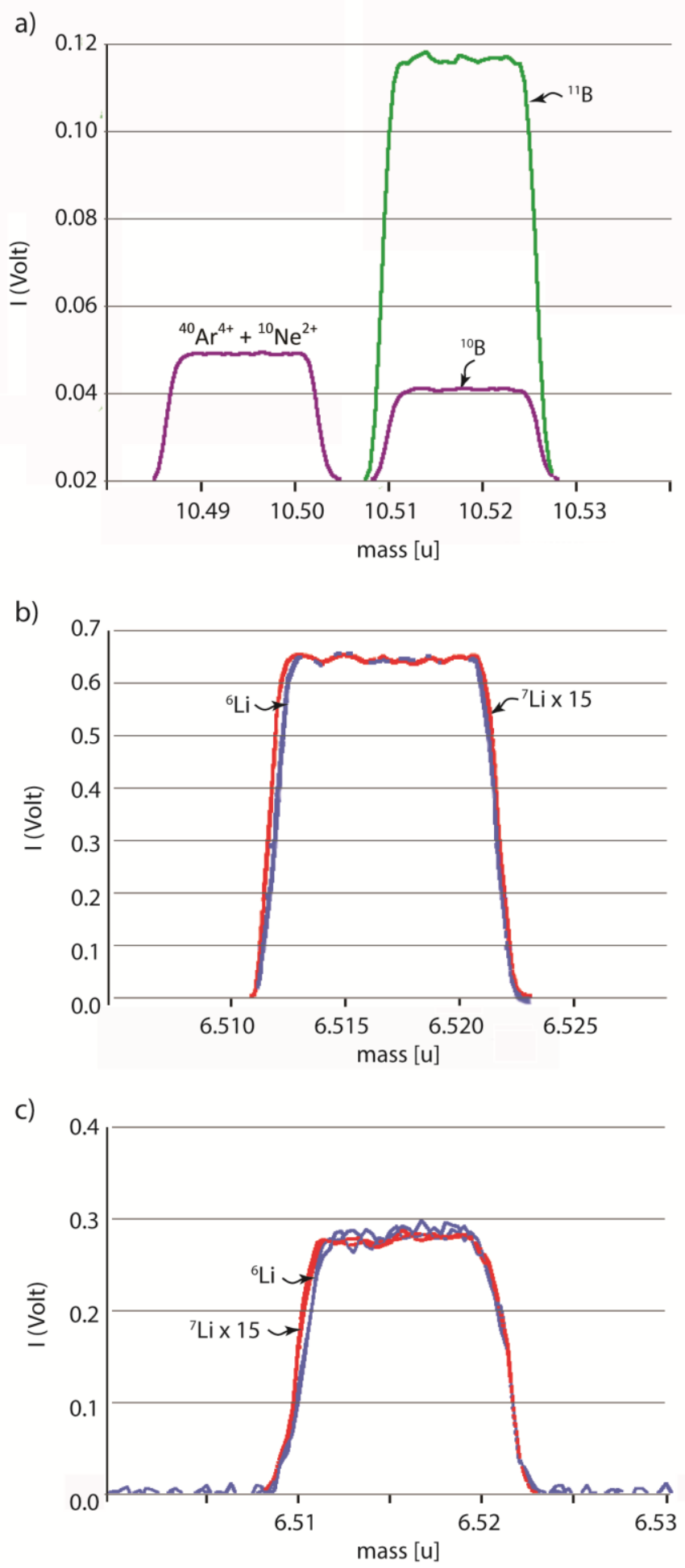

Figure 1 
a)

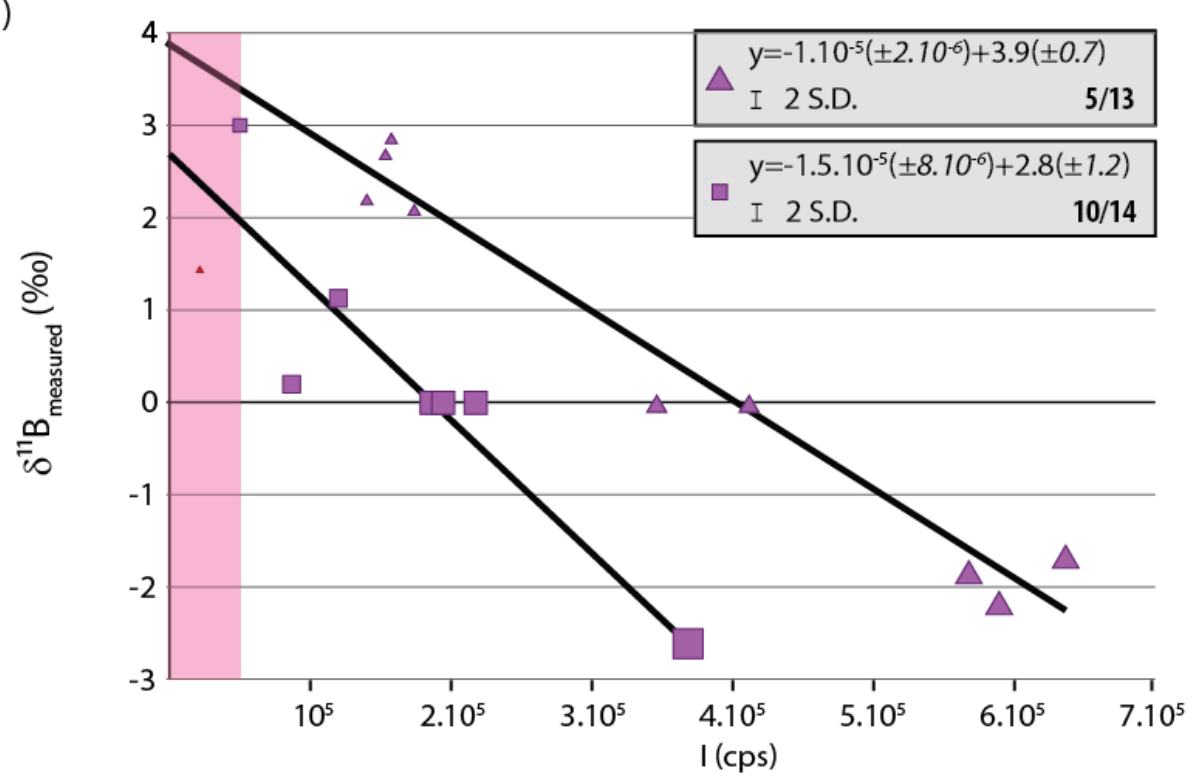

Spot size

$75 \mu \mathrm{m}$

$\square \Delta \quad 50 \mu \mathrm{m}$

$\square \Delta \quad 40 \mu \mathrm{m}$

$\triangle \quad 25 \mu \mathrm{m}$

. $\quad 10 \mu \mathrm{m}$

b)

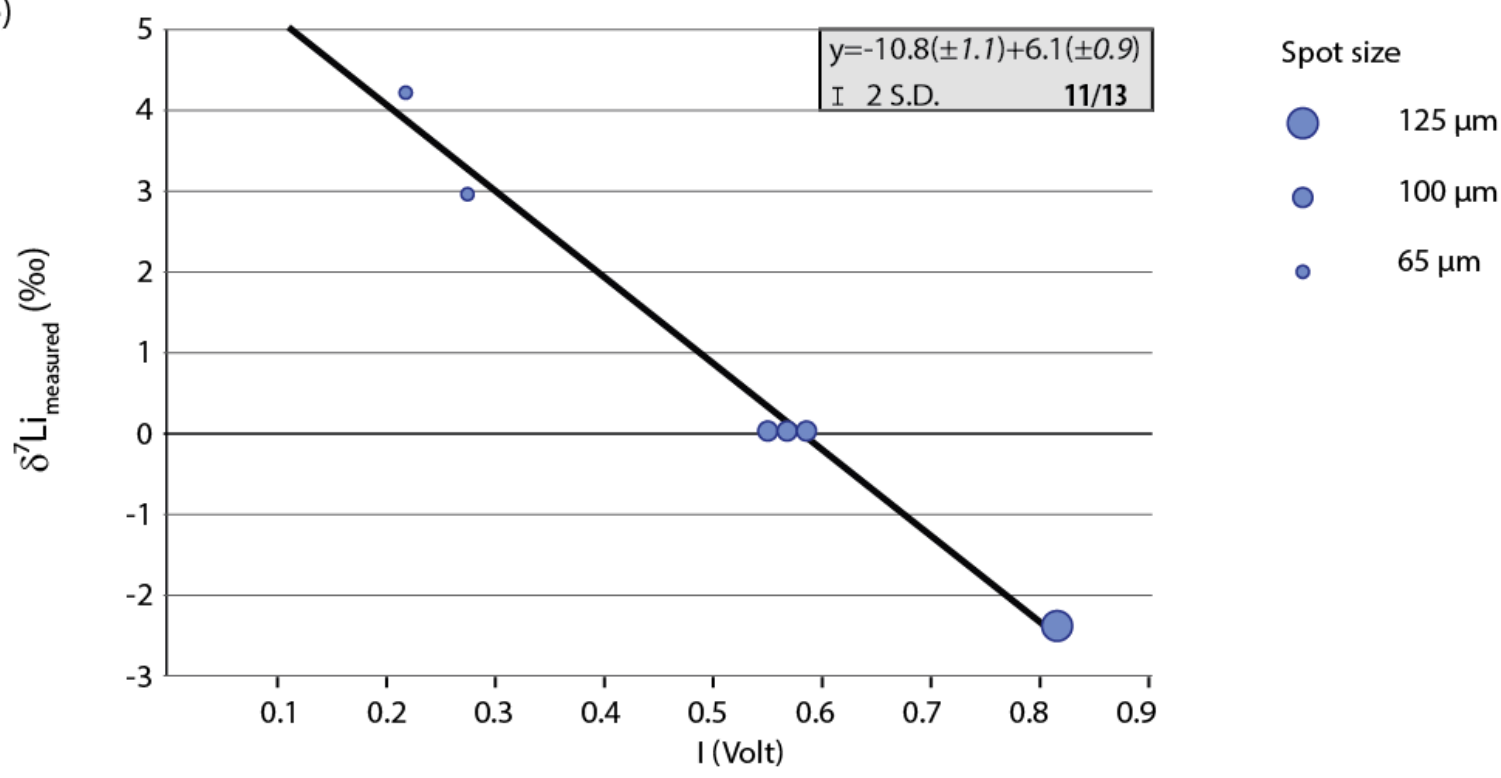

Figure 2 


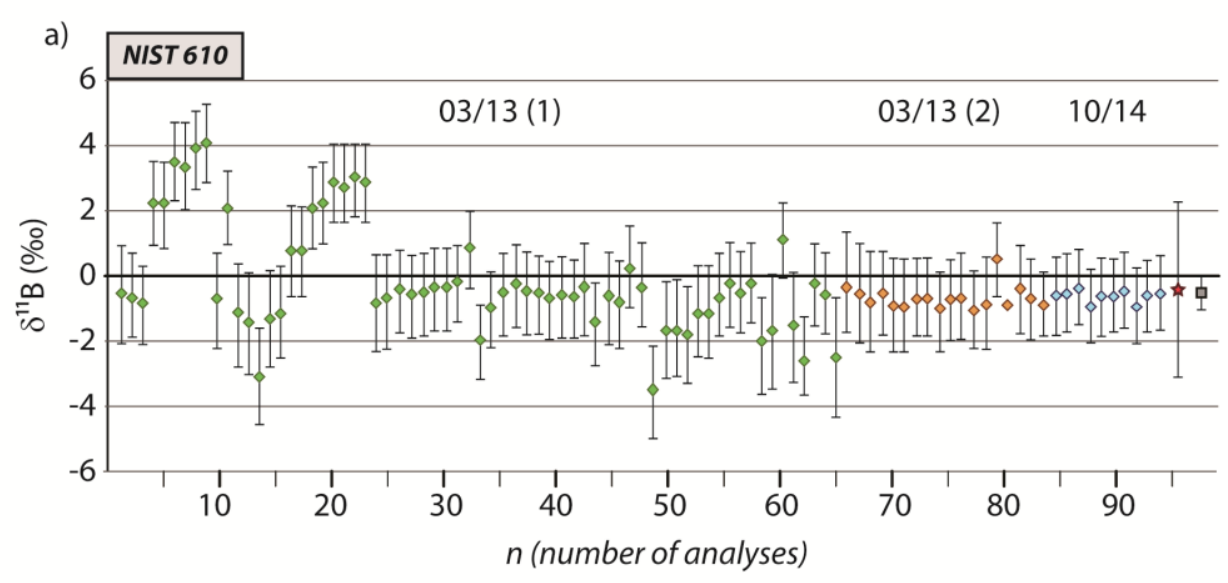

$\square$ reference

$\diamond$ Fc measurement

क $\mathrm{MR}$ measurement

average

$\triangle \mathrm{IC}$ measurement

O LR measurement

$04 / 13$ session of

analysis (month/year)
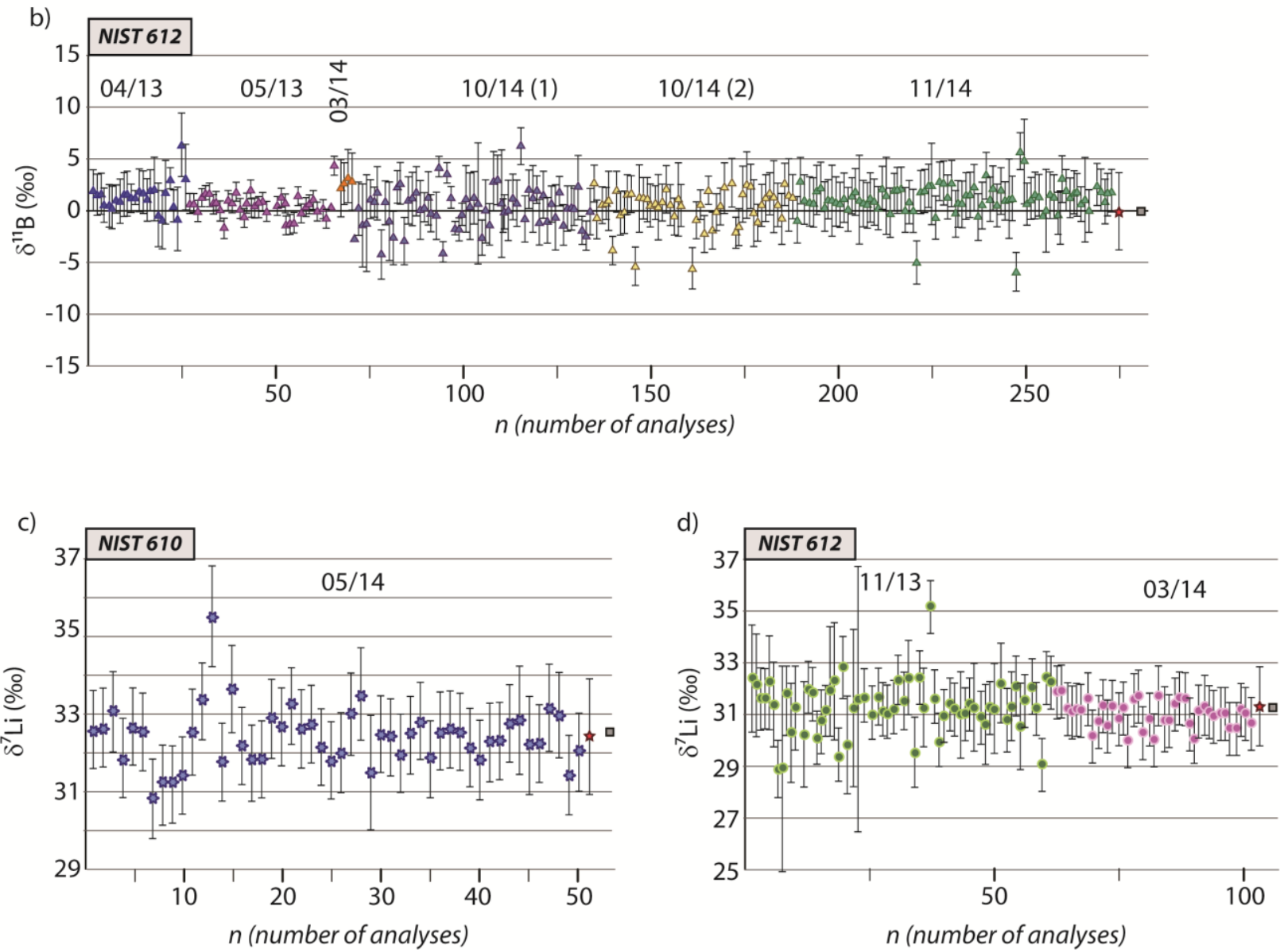

Figure 3 

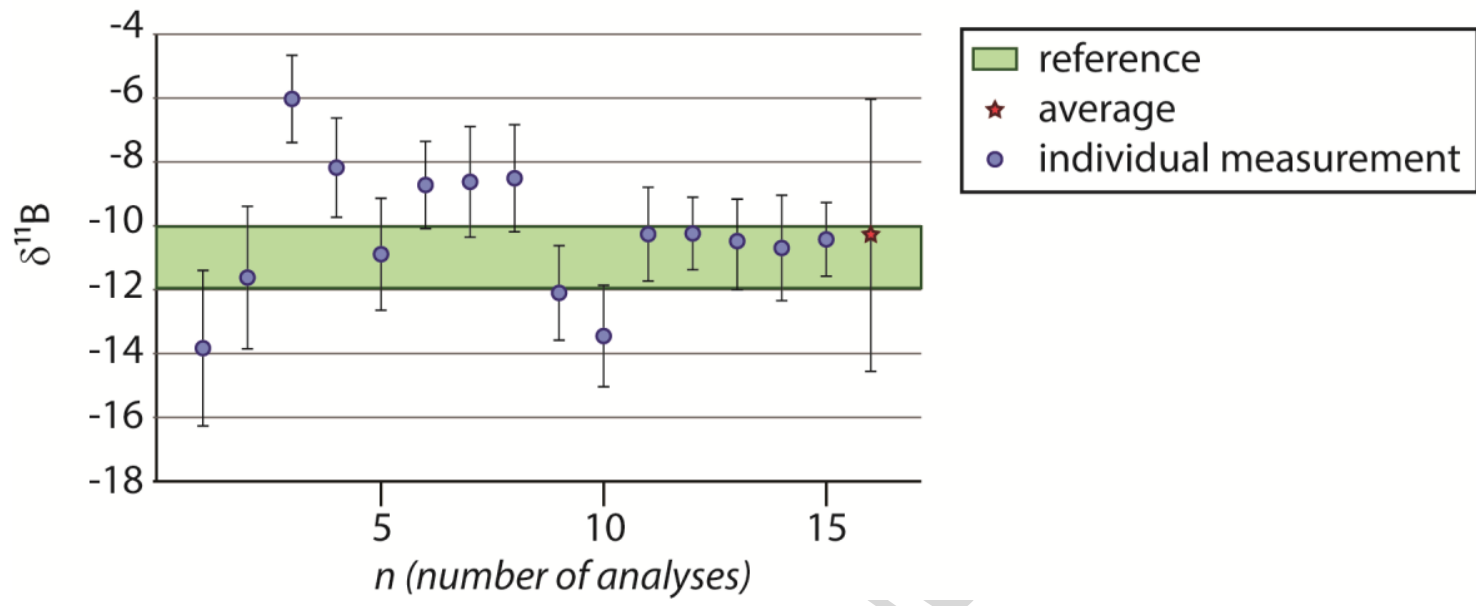

Figure 4 

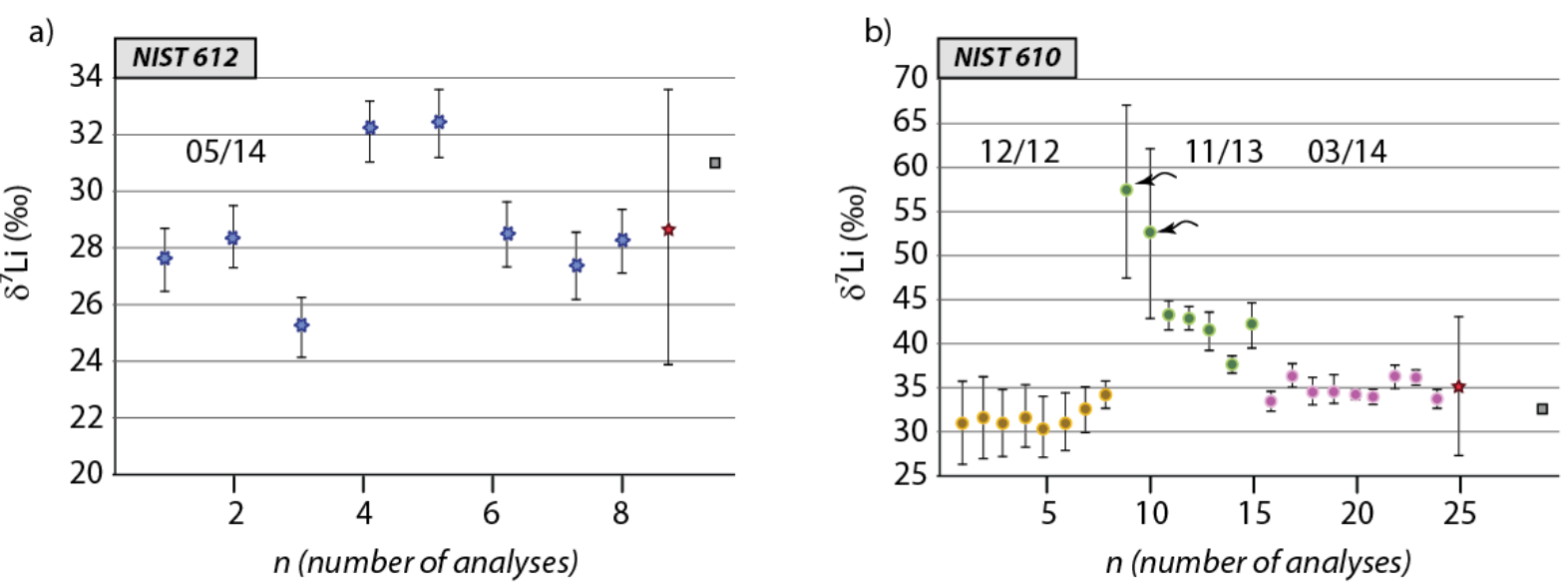

\begin{tabular}{|c|c|c|c|}
\hline 口 reference & 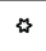 & MR individual measurement & average \\
\hline$\leadsto 2 \mathrm{~V}$ & $\circ$ & LR individual measurement & \\
\hline
\end{tabular}

Figure 5 

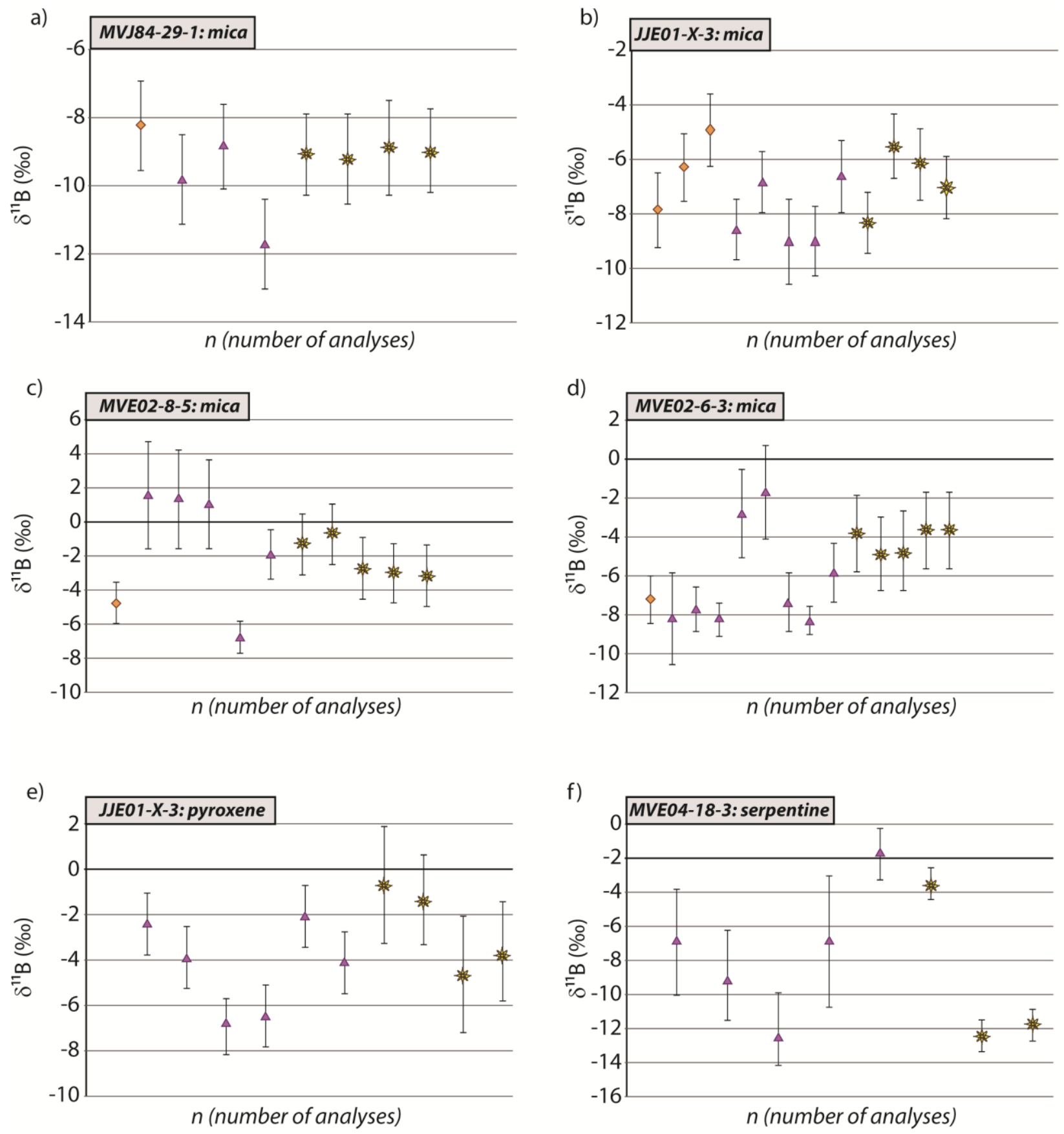

$\diamond$ Fc measurement $\quad \Delta \mathrm{IC}$ measurement $\quad$ SIMS measurement

Figure 6 

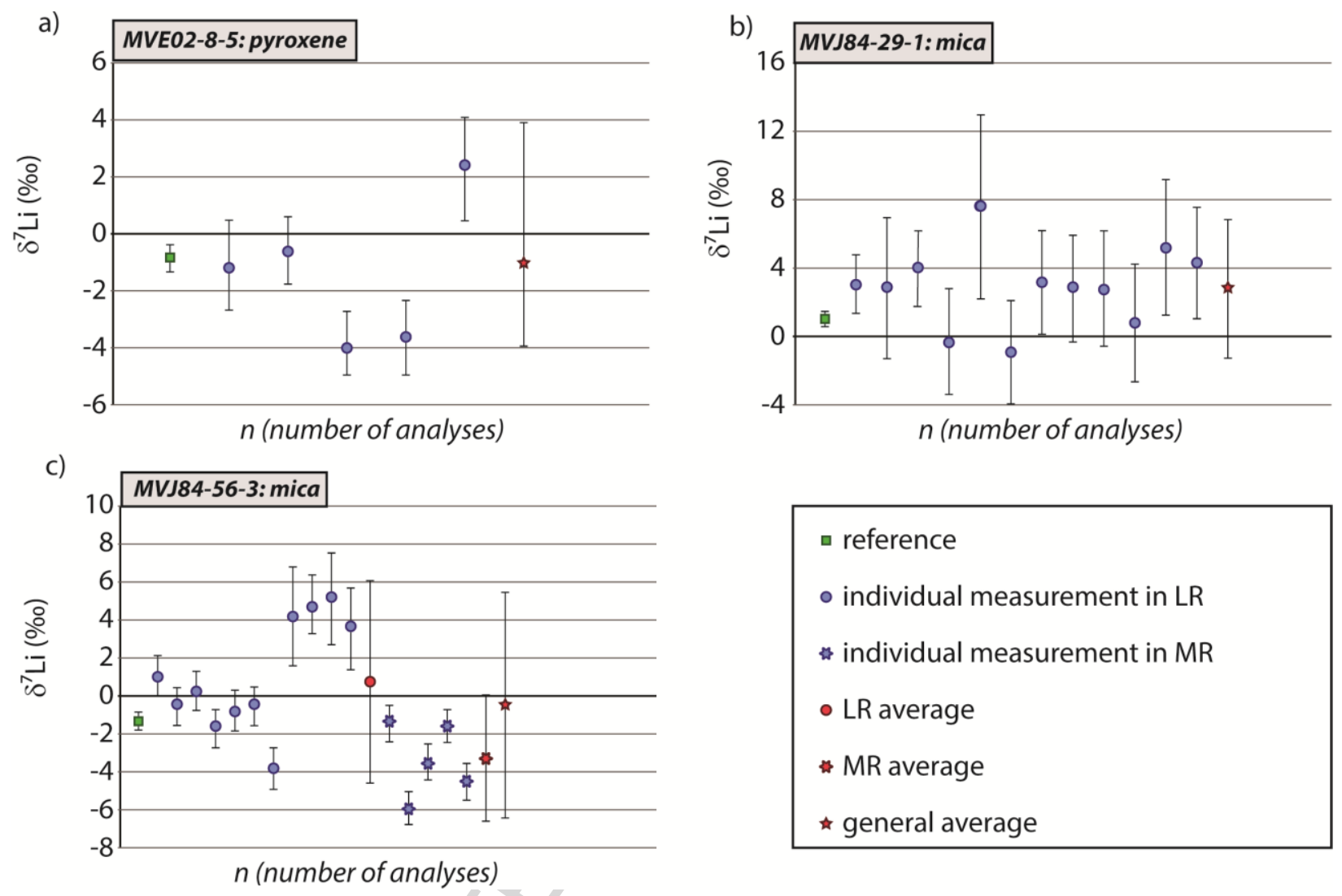

$$
\begin{aligned}
& \text { - reference } \\
& \text { • individual measurement in LR } \\
& \text { - individual measurement in MR } \\
& \text { - LR average } \\
& \text { - MR average } \\
& \text { * general average }
\end{aligned}
$$

Figure 7 
Table 1: Reference material values for $B$ and $\mathrm{Li}$ isotopes.

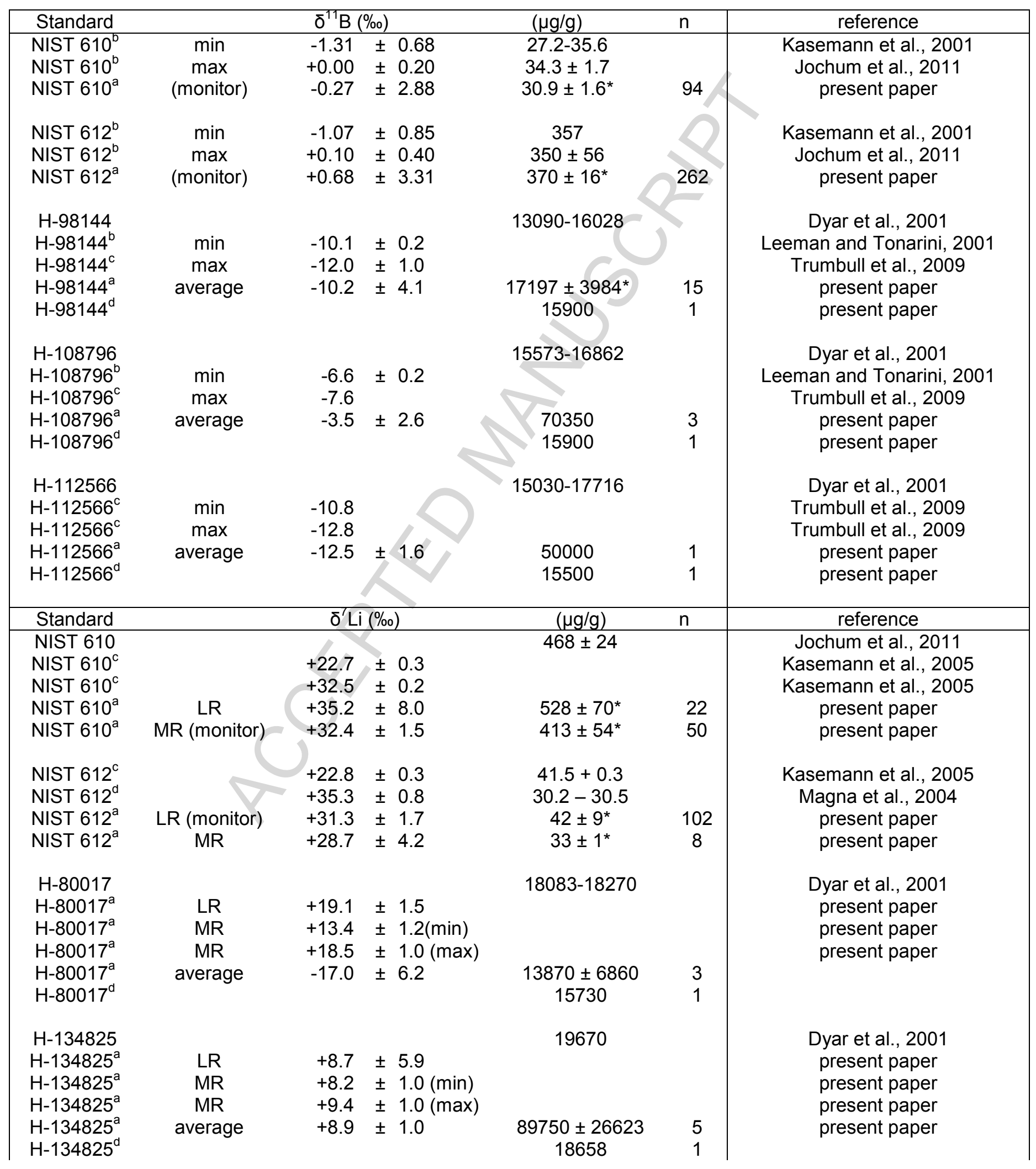


$\mathrm{H}-98144$

$\mathrm{H}-98144^{\mathrm{C}}$

$\mathrm{H}-98144^{\mathrm{a}}$

$\mathrm{H}-98144^{\mathrm{a}}$

$\mathrm{H}-98144^{\mathrm{d}}$

$\mathrm{H}-112566$

$\mathrm{H}-112566^{\mathrm{C}}$

$\mathrm{H}-112566^{\mathrm{a}}$

$\mathrm{H}-112566^{\mathrm{a}}$

$\mathrm{H}-112566^{\mathrm{d}}$
$+7.1$

$+32.1 \pm 2.3$

$+13.0 \pm 5.8$
$538-2387$

2333

$2131 \pm 260^{*}$

$1814 \pm 440^{*}$

2950

$125-192$

$+5.6 \pm 0.2$

$+23.6 \pm 6.4$

$+9.9 \pm 2.7$
LR

MR
180
$210 \pm 48^{*}$
$136 \pm 27^{*}$

222
Dyar et al., 2001

Marschall, pers. comm.. present paper present paper present paper

Dyar et al., 2001 Marschall, pers. comm. present paper present paper present paper

${ }^{\mathrm{a}}$ analyzed by LA-MC-ICPMS, ${ }^{\mathrm{b}}$ analyzed by TIMS, ${ }^{\mathrm{c}}$ analyzed by SIMS, ${ }^{\mathrm{d}}$ analyzed by LA-ICP-MS

(monitor) indicates that this average is obtained on the standards used to monitor the measurements, all the other averages presented in that table were acquired on standards considered as unknown samples. min and max indicate respectively the minimum and maximum values available in literature for a given standard, $L R$ means Low Resolution, and $M R$, medium Resolution.

* concentrations in $\mathrm{B}$ and $\mathrm{Li}$ calculated by comparison of the intensities of the standard and of the unknown sample (LA-MC-ICPMS), with the following equation $[i]_{\text {sample }}=[i]_{\text {standardx }} \frac{I_{x a m p l e}}{I_{s t a n d a r d} \times\left(\frac{\Delta_{s a m p l e}}{\sigma_{s t a n d a r d}}\right)^{2}}$,

where [i] is the concentration in $\mathrm{B}$ or $\mathrm{Li}$, / the intensity of ${ }^{11} \mathrm{~B}$ and ${ }^{7} \mathrm{Li}$, and $\emptyset$ the laser spot diameter. 
Table 2: Results on GSZ samples for B isotopes

\begin{tabular}{|c|c|c|c|c|}
\hline sample & method & $\delta^{11} \mathrm{~B}(\% \circ)$ & {$[\mathrm{B}](\mu \mathrm{g} / \mathrm{g})$} & $\mathrm{n}$ \\
\hline MVJ84-29-1 - mica & Fc & $-7.9 \pm 1.2$ & $24^{*}$ & 1 \\
\hline MVJ84-29-1- mica & IC & $-8.0 \pm 1.8(\max )$ & & \\
\hline MVJ84-29-1- mica & IC & $-9.9 \pm 1.8(\mathrm{~min})$ & & \\
\hline content average & IC & & $77 \pm 5^{*}$ & 3 \\
\hline MVJ84-29-1- mica & SIMS & $-8.8 \pm 1.4(\max )$ & & \\
\hline MVJ84-29-1- mica & SIMS & $-9.2 \pm 1.3(\min )$ & & \\
\hline content average & SIMS & & $87 \pm 14^{@}$ & 3 \\
\hline MVJ84-29-1- mica & Qp & & $30 \pm 5$ & 12 \\
\hline JJE01-X-3 - mica & Fc & $-5.5 \pm 1.1(\max )$ & & \\
\hline JJE01-X-3 - mica & & $-7.1 \pm 1.3(\mathrm{~min})$ & & \\
\hline content average & & & $75 \pm 34^{*}$ & 3 \\
\hline JJE01-X-3 - mica & & $-4.8 \pm 1.2(\max )$ & & \\
\hline JJE01-X-3 - mica & IC & $-7.2 \pm 1.1(\min )$ & & \\
\hline content average & IC & & $28 \pm 7^{*}$ & 5 \\
\hline JJE01-X-3 - mica & SIMS & $-5.5 \pm 1.2(\max )$ & & \\
\hline JJE01-X-3 - mica & SIMS & $-8.3 \pm 1.2(\mathrm{~min})$ & & \\
\hline content average & SIMS & & $323 \pm 94^{@}$ & 4 \\
\hline JJE01-X-3 - mica & Qp & & $106 \pm 52$ & 8 \\
\hline JJE01-X-3 - pyroxene & IC & $-3.9 \pm 1.3(\max )$ & & \\
\hline JJE01-X-3 - pyroxene & IC & $-6.8 \pm 1.3(\min )$ & & \\
\hline content average & IC & & $1.1 \pm 0.8^{*}$ & 4 \\
\hline
\end{tabular}




\begin{tabular}{|c|c|c|c|c|}
\hline JJE01-X-3 - pyroxene & SIMS & $-0.6 \pm 2.5(\max )$ & & \\
\hline JJE01-X-3 - pyroxene & SIMS & $-4.7 \pm 2.2(\mathrm{~min})$ & & \\
\hline content average & SIMS & & $2.5 \pm 2.6^{@}$ & 3 \\
\hline JJE01-X-3 - pyroxene & Qp & & & \\
\hline MVE02-8-5 - mica & Fc & $-4.0 \pm 1.1$ & $66^{*}$ & 1 \\
\hline MVE02-8-5 - mica & IC & $+1.5 \pm 3$ & & \\
\hline MVE02-8-5 - mica & IC & $-6.7 \pm 1.0(\mathrm{~min})$ & & \\
\hline content average & IC & & $123 \pm 45$ & 4 \\
\hline MVE02-8-5 - mica & SIMS & $-0.7 \pm 1.9(\max )$ & & \\
\hline MVE02-8-5 - mica & SIMS & $-3.1 \pm 1.9(\min )$ & & \\
\hline content average & SIMS & & $139 \pm 65^{@}$ & 5 \\
\hline MVE02-8-5 - mica & Qp & & $98 \pm 70$ & 15 \\
\hline MVE02-6-3 - mica & Fc & $-6.5 \pm 1.2$ & $26^{*}$ & 1 \\
\hline MVE02-6-3 - mica & IC & $+0.5 \pm 2.5(\max )$ & & \\
\hline MVE02-6-3 - mica & IC & $-7.2 \pm 0.9(\mathrm{~min})$ & & \\
\hline content average & $I C$ & & $88 \pm 38 *$ & 6 \\
\hline MVE02-6-3 - mica & SIMS & $-3.7 \pm 2.0(\max )$ & & \\
\hline MVE02-6-3 - mica & SIMS & $-4.9 \pm 2.0(\min )$ & & \\
\hline content average & SIMS & & $166 \pm 36^{@}$ & 5 \\
\hline MVE02-6-3 - mica & Qp & & $67 \pm 22$ & 4 \\
\hline MVE04-18-3-antigorite & IC & $+0.0 \pm 1.5$ & & 1 \\
\hline MVE04-18-3-antigorite & IC & $-11.0 \pm 1.4$ & & \\
\hline content average & & & $184 \pm 130 *$ & 5 \\
\hline
\end{tabular}




$\begin{array}{ccc}\text { MVE04-18-3-antigorite } & \text { SIMS } & -3.4 \pm 1.0 \text { (max) } \\ \text { MVE04-18-3-antigorite } & \text { SIMS } & -12.5 \pm 0.9 \text { (min) } \\ \text { content average } & \text { SIMS } & \\ \text { MVE04-18-3-antigorite } & \text { Qp }\end{array}$

$43 \pm 14^{@}$

$12 \pm 2$ 3

3

Analyses by LA-MC-ICPMS: FC = Faraday cup, IC = Ion Counter; SIMS = analyses by SIMS

concentrations in B calculated by comparison of the intensities of the standard and of the unknown sample: * LAMC-ICPMS, ${ }^{@}=$ SIMS; Qp = concentrations in B measured by LA-ICP-MS

min and max represent respectively the lowest and highest values measured by LA-MC-ICP-MS for $\delta^{11}$ B for a given sample. 
Table 3: Results on GSZ samples for Li

\begin{tabular}{|c|c|c|c|c|}
\hline sample & method & $\delta^{7} \mathrm{Li}(\%)$ & [Li] $(\mu \mathrm{g} / \mathrm{g})$ & $\mathrm{n}$ \\
\hline MVE02-8-5 - WR & wet & $-0.9 \pm 0.4$ & 34 & \\
\hline MVE02-8-5 - pyroxene & LR & $+2.3 \pm 2.1(\max )$ & & \\
\hline MVE02-8-5 - pyroxene & LR & $-3.9=$ & & \\
\hline MVE02-8-5 - px average & $L R$ & & $21 \pm 13^{*}$ & 5 \\
\hline MVE02-8-5 - px average & Qp & & $16 \pm 14$ & 15 \\
\hline MVJ84-29-1 - mica & wet & $+1.2 \pm 0.4$ & 16 & \\
\hline MVJ84-29-1- mica & LR & $+7.7 \pm 5.2(\max )$ & & \\
\hline MVJ84-29-1- mica & LR & $-0.6 \pm 2.9(\mathrm{~min})$ & & \\
\hline MVJ84-29-1- mica average & $L K$ & $+3.2 \pm 4.3$ & $153 \pm 64^{*}$ & 12 \\
\hline MVJ84-29-1- mica average & 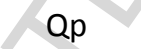 & & $199 \pm 54$ & 12 \\
\hline MVJ84-56-3 - albite & wet & $-1.5 \pm 0.4$ & 37 & \\
\hline MVJ84-56-3 - albite & LR & $+4.6 \pm 2.8(\max )$ & & \\
\hline MVJ84-56-3 - albite & LR & $-4.5 \pm 1.2(\min )$ & & \\
\hline MVJ84-56-3 - albite average & $L R$ & $+0.5 \pm 5.6$ & & 11 \\
\hline MVJ84-56-3 - albite & MR & $-0.6 \pm 1.1(\max )$ & & \\
\hline MVJ84-56-3 albite & MR & $-5.4 \pm 1.1(\min )$ & & \\
\hline MVJ84-56-3 - albite average & $M R$ & $-2.8 \pm 3.7$ & & 5 \\
\hline MVJ84-56-3 - albite average & all & $-0.5 \pm 5.9$ & $38 \pm 9 *$ & 16 \\
\hline MVJ84-56-3 - mica & Qp & & $31 \pm 8$ & 7 \\
\hline
\end{tabular}

Wet = data from Simons et al., (2010), LR = analyses by LA-MC-ICPMS in low resolution, MR = analyses by LA-MCICPMS in medium resolution 
* concentrations in Li calculated by comparison of the intensities of the standard and of the unknown sample (LAMC-ICPMS) (see Table 1), Qp = concentrations in Li measured by LA-ICP-MS

$\min$ and max represent respectively the lowest and highest values measured by LA-MC-ICP-MS for $\delta^{7}$ Li for a given sample. 